\title{
ポジティブ感情の役割11 一その現象と機序
}

\author{
山 崎 勝 之 \\ 鳴門教育大学人間形成講座
}

「ポジティブ心理学運動」に刺激され, これまで多くの研究がポジティブ感情の役割を調べてきた. 本論 文では，まず，ポジティブ感情の定義と測定方法にかかわる問題のいくつかを明らかにした，特に，ポジ ティブ感情の多くの種類が未だ考慮されていない現状を指摘し, あわせて測定方法の精度の低さの問題を強 調した. 続いて, ネガティブ感情と比較しながら, ポジティブ感情がもたらす多くの恩恵が, 知覚, 情報処 理, 健康, 対人関係などの広範囲にわたりレビューされた。そのレビューでは, 過去に扔いてポジティブと ネガティブ感情にかかわる知見の不一致が生じた理由を考察し，不一致の原因を探りながら，両感情にかか わる一致した見解の確立の可能性をさぐった，最後に本論文は，これらの恩恵をむたらす仮説的メカニズム について明らかにした。本論文の全体を通して, 広範囲にわたるこの種の研究がもつ重要な問題を指摘し, それと同時に, 今後実施すべき研究を示唆した。 今後の研究としては, 文化差ならびに介入研究が強調され た.

キーワード : ポジティブ感情, ネガティブ感情, ポジティブ感情の役割, 役割のメカニズム

\section{1. ポジティブ心理学の勃興}

近年, ポジティブ心理学 (positive psychology) が勃興し、それは,まさに運動 (movement) と呼 ベる勢いをもっている. ポジティブ心理学は, こ れまでの, 人間のネガティブな側面（病や暴力な ど）を強調してきた研究姿勢への大きな巻き返し ととらえることができる運動である，その仕掛け 人とむいえる Seligman, M.E.P.によると，ポジティ ブ心理学は, 彼がアメリカ心理学会の会長に選出 されて（1996 年）間むなく興ったということであ るから,つい最近のことである.

\section{(1) ポジティブ心理学の研究対象}

Seligmanによれば，ポジティブ心理学の目的

1) 本研究は, 平成 17 年度日本学術振興会科学研究費 補助金（基盤研究 C, 課題番号 17530510）の補助を受 けた.
は，生活の悪い面を修復することにとらわれてい たこれまでの心理学を, 生活のよい面をも打ち立 てる心理学に変えることにある (Seligman, 2002a). その研究対象は広く, 主観的なレベル（幸福感や 希望など），個人レベル（創造性や寛大さなど）, 集団レベル（個人を善良な市民に育てる制度や市 民美徳，たとえば，責任感や愛他性など）など, 人間のポジティブな側面を対象にする研究があて はまり, 基礎から応用まで多様な広がりをみせて いる (Seligman \& Csikszentmihalyi, 2000).

あっとも, このポジティブ心理学は, 運動面が 強調されているように，功らずしも十分な科学 性をむっているとは言えない.この科学性の欠如 と現実からの乘離をきびしく突き,この運動のあ り方を批判するむきむ少なくない（たとえば, Lazarus, 2003). しかし，この運動に触発され自然 と活発化してきた個々の研究領域は, 科学研究と 
して耐えうる意義深い知見を提起しつつある。ま た, 若手を中心とした個々の研究者は, ポジティ ブ心理学という大きな潮流を意識することなくポ ジティブ心理学の範疇に入る研究を行っている場 合む少なくない。

\section{（2）ポジティブ感情研究}

このポジティブ心理学の研究領域の中でも, 研 究が集中的に行われている領域の一つがポジティ ブ感情 (positive affect or emotion) である. 後述す るように，ポジティブ感情は，多様な機能と役割 をあって喚起されることが明らかにされつつある が, 心理学における感情の研究は, ネガティブな あのが主流であったことは事実である. Fredrickson (2003) によると, その理由がいくつか示唆さ れる．まず，ポジティブ感情の種類が少なく，ま た個々のポジティブ感情は比較的弁別が困難で あったことが理由としてあげられる。また，ネガ ティブ感情はその種類により特徵的な表情や自律 神経系の反応をもたらすが，ポジティブ感情はそ のような弁別特徵をむつことが少ない.さらに， 個々のネガティブ感情は特定の行動と遂行に結び つき，その行動の喚起を支える機能を備えている が，これに類したポジティブ感情の機能はほとん ご確認されてこなかったことも理由の一つである. こうして, 多くの研究者は, ネガティブ感情がも つこれらのより明確な特徵を拠り所として研究を 推進し，諸々のモデルを打ち立ててきた。

しかしながら，堰を切ったように始まった近年 のポジティブ感情の研究は, ネガティブ感情と比 べても遜色のない特定される機能を多数明らかに しつつある。本論文においては, 近年のこの領域 の研究を外観しながら，研究がピークを超えた観 のあるこの研究領域を整理し, 今後の発展の方向 を随所に指摘したい，なお，本稿では，できる限 り, 状態的なポジティブ感情 (state positive affect) の研究を対象にすることを目指した。 ポジティブ 感情には, 他に特性的ポジティブ感情 (trait or dispositional positive affect) と命名し, 性格に類似し
た概念としてポジティブ感情を扱う研究も少なく ない。しかしながら，特性としてのポジティブ感 情は, 楽観主義 (optimism) やセルフ・エスティー ム (self-esteem) など他の特性との概念上の重なり や正の相関が極めて高い. 特性ポジティブ感情の 効果を, このような他の特性からの効果と切り離 して確認することは困難を極めるとの判断が, 状 態的ポジティブ感情に焦点をあてた理由である.

\section{2. ポジティブ感情の構成と測定}

\section{（1）感情の次元とポジティブ感情の種類}

本論文では, affect または emotion の訳として 感情という言葉をあてている。その必要性がある 場合をのぞき，両者を区別する用語を採用してい ない理由は後述する。 あえて, 訳し分けるなら, 感情と情動ということであろうが，日本語におい てもその区別は曖昧な場合が多く, 少なくとも実 際の研究でその区別が意味をなす場合はほとんど ない。アメリカ（合衆国）においても，この事情 は同様である. Russell (2003) では, 核感情 (core affect) を出発点とし, 感情の質 (affective qualily), 帰属された感情 (attributed affect), 感情制御 (affect regulation) の概念を導出し, それらに評価 (appraisal) や行為 (action) などが加わって, 特定 の感情 (emotion) の原型が生じるという仮説を提 起しているが (Russell, 2003, Fig. 3 参照), やはり, 実際にこれら諸概念を操作した研究はほとんど見 あたらない，用語を㛜密に区別することに研究上 の意義はほとんど見いだせない現状にあると言え る.

これに対して, 感情と情動を区別して，その区 別を考慮した上で研究を行おうとする研究者は何 名か確認できる.たとえば, Fredrickson (2001) で は, これまの研究から, 情動は感情とは次の点に おいて区別されると見なし, 彼女自身, 感情 (affect) よりも情動 (emotion) という用語を使用する ように努めている. 第 1 に, 情動は特定の対象を むつが，感情には特定の対象がない，第 2 に，情 
動は一般に短時間しか持続せず, 感情は長時間持 続する，第 3 に，情動は喜び (joy) や怒り (anger) のように明確なカテゴリーに分類できるが，感情 は快 (pleasantness) と賦活 (activation)，あるいは ポジティブとネガティブ情動的賦活の 2 次元にお いて変化するとしている.

第 3 にあげた感情の次元については，異論がな いわけではない，自己報告された感情についての 2 因子モデルでは, 一般に, 因子分析における回 転前の第 1 因子は, 誘意性次元（valence dimention; 快 - 不快), 第 2 の因子は, 賦活あるいは覚 醒次元 (active or arousal dimension; 活性化一不 活性化）であることが指摘され（たとえば, Larsen \& Diener, 1992), ヴァリマックス回転後の 第 1 因子はポジティブ賦活, 第 2 因子はネガティ ブ賦活とされている（たとえば, Watson, Wiese, Vaidya \& Tellgen, 1999). この 2 次元構造に対し て, 円環構造が Russell (1980) らによって提起さ れ, 喜び (pleasure, 0 度), 興奮 (excitement, 45 度), 覚醒 (arousal, 90 度), 困惑 (distress, 135 度), 不快 (displeasure, 180 度), 抑うつ(depression, 225 度), 眠気 (sleepiness, 270 度), 弛緩 (relaxation, 315 度) が想定されている。しかし， Terracciano, McCrae, Hagemann \& Costa (2003) に よると, この円環モデルは, 特定の集団に適用で きても，普遍的なモデルとはみなされず，現段階 では, 上述の 2 次元構造の適用を想定した方がよ い.

しかしながら，このような感情と情動の弁別の 試みにもかかわらず, 多くの研究者が両者の区別 を明確にせず使用している現状があり, どちらか の用語を選択的に使用しようとする Fredrickson や Folkman らの論文をみても, 両用語が同じ意味で 使用されているケースが見かけられる。このよう な現状をみると，読者は，これまでのこの領域の 論文を参照するときには, 両用語は同じ意味で使 用されていると考えてよい場合が多い。 また，実 際に, ポジティブ感情や情動の具体的種類として,
たとえば，Fredrickson (1998) は，喜び (interest), 興味 (interest), 満足 (contentment), 愛 (love) を あげ，感情尺度として多用されているポジティ ブ・ネガティブ感情スケジュール (Positive and Negative Affect Schedule; PANAS; Watson, Clark \& Auke, 1988) は, ポジティブ感情尺度に, 注意深い (attentive)，興味をむった (interested)，機敏な (alert), わくわくした (excited), 熱狂した (enthusiastic), 気合いの入った (inspired), 自信のあ る (proud), きっぱりとした (determined), 力強 い (strong), 活発な (active) をあげている。しか し, Fredrickson らの一部の研究（たとえば, Fredrickson, Mancuso, Branigan \& Tugade, 2000; Fredrickson \& Branigan, 2005) を除いて，これらの 感情の細分化の扱いは, ポジティブ感情とネガ ティブ感情の 2 次元構造である場合がほとんどで, 詳細な概念弁別や用語弁別が具体的な研究の水準 では意味をなさないのが，これまでの研究の実状 である。

また，ポジティブ感情をもたらす原因も多様で あるが，その原因の違いによりポジティブ感情そ のあのが異なる可能性もある. 実験室においてポ ジティブ感情を生起させる場合, 楽しい映像をみ せたり（たとえば，Fredrickson \& Levenson, 1998; Homenover, 2003), 陽気な音楽を聴かせたり (Erber, Wegner \& Therriault, 1996), キャンディな どのギフトを与えたり（たとえば, Estrada, Isen \& Young, 1997; Isen, Niedenthal \& Cantor, 1992), 楽 しいシナリオを読んだり (Lucas \& Baird, 2004)す ることなど様々であるが, ポジティブ感情の生起 方法によるポジティブ感情の相違については考慮 されていない.

他にも，ポジティブ感情を生起させる原因や状 況を考えた場合, 多様なポジティブ感情の存在が 示唆される，たとえば，一般に条件づけ事態では, 正の強化はポジティブ感情をあたらすことが考え られるが，この強化から導出されたポジティブ感 情は上述の実験室において生起されたポジティブ 
感情と同じかどうかは明らかではない，また，発 達過程に注目すると，生後ますない乳児の微笑 （自発的微笑や人の顔に対する微笑），また，随伴 関係の発見後の微笑，腋の下等の刺激による笑 い,さらには, 微笑 (smile) と笑い (laughter), デュシャンヌ微笑 (Duchenne laughter or smile; 口だけでなく目のまわりの筋も含めて表現される 顔満面の笑みで, 強い喜びを示す）と非デュシャ ンヌ微笑 (non-Duchene laughter or smile) の違い など，ポジティブ感情の生起にまつわる現象は複 雑多岐にわたるが，ポジティブ感情における現段 階の研究はこのような細部を考慮していない状況 にある。デュシャンヌ微笑は, 非デュシャンヌ微 笑と比較すると，ストレスの低減やより良好な対 人関係をもたらすという，微笑の型による弁別的 な研究が散見され（たとえば，Keltner \& Bonanno, 1997）, これらの研究はポジティブ感情の種類と その機能が異なることを示唆している.

\section{（2） ポジティブ感情とネガティブ感情の関係}

上述の，感情に関する 2 次元構造から屯示唆さ れるように，ポジティブとネガティブな感情は 1 次元上の両端にある関係にはない。一般に両感情 は負の関係にあるが，その相関はかなり低く，た とえば, PANAS の標準化論文 (Watson et al., 1988) では, -.12 から -.23 という低い負の相関が得ら れており，無相関という研究む見られる（たとえ ば, Pettit, Kline, Gencoz, Gencoz \& Joiner, 2001). ポジティブ感情は強いストレス状況においても比 較的高頻度で生じ，抑うつや困惑が高まっていて も同時に生起することが指摘されている (Folkman, 1997; Moskowitz, 2003; Viney, 1986). Wortman \& Silver (2001) は, 乳幼児突然死で子どもを失った 親へのインタビューで, 子どあの死後 3 か月まで には，ポジティブ感情はネガティブ感情よりも頻 繁に報告されるようになったとしている．

また，Van Yperen (2003) の研究においても，ポ ジティブとネガティブ感情の高低を扱い, 両感情 ともに高い場合をも想定し，ポジティブ感情の生
起がネガティブ感情と仕事の遂行の負の関係に干 渉し，ネガティブ感情の仕事への悪影響を緩和す ることを示唆している。これらの結果は, ポジ ティブ感情とネガティブ感情が異なった神経経路 によって支配され (Lane, Reiman, Bradley, Lang, Ahem, Davidson \& Schwartz, 1997), 両者は異なっ た神経生理学的メカニズムを介して心身の機能に 影響を及ぼす (Isen, 2002; Taylor, Dickerson \& Klein, 2002)ことからあ予想されることである.こ うして, ポジティブ感情とネガティブ感情の生起 が比較的独立していることが示唆されるが，その 独立性は条件により变化することも示唆され, 感 情が強く喚起されるほど，両者の逆の関係は強ま ることが報告されている (Diener \& Emmons, 1984).

このような両感情の独立性からむ, 両感情特有 の役割や機能が想定される。ネガティブ感情は, 目下の問題への集中的な対処を可能にし，ポジ ティブ感情は以下に紹介される数多くの恩恵をも たらす。両感情の機能は，しばしば，森と木を見 るときの例にたとえられ，木を見て森を見ないの がネガティブ感情で, 森を見て木を見ないのがポ ジティブ感情となる。こうして, 両感情がそれぞ れ特有の機能をもつことを想定すると, 真に適応 的な条件は, 状況に応じて両感情を柔軟に使い分 けることであろう。しかしながら, 現行の研究は, ネガティブとポジティブの感情の高低を別に取り 扱い，両者の柔軟なバランスをとらえる研究はほ とんど行われていない，つまり，ネガティブ感情 を喚起しやすい人，ポジティブ感情を喚起しやす い人に加えて, 両感情をバランスよく喚起する人 の存在が仮定され, その人の適応力は大きいこと が想像される. しかしながら, 両感情のバランス がよいという状態を測定する方法の困難さにも妨 げられ，今のところこの種の研究は推進されてい ない.

\section{(3) ポジティブ感情の測定}

アメリカにおけるポジティブ感情の測定法につ 
いては, Lucas, Diener \& Larsen (2003) に簡潔に紹 介されているが，ここでは, 日本での測定法を含 めて, 質問紙法を中心にその特徴を, 若干の問題 点とともに記述する.

ポジティブ感情を測定する場合, 質問紙を用い ることが圧倒的に多い。その質問紙は, Intensity and Time Affect Survey (ITAS; Diener, Smith \& Fujita, 1995), Brief Mood Introspection Scale (Mayer \& Gaschke, 1988), Bradburn Affect Balance Scale (Bradburn, 1969), Center for Epidemiologic Studies Depression Scale (CES-D; Radloff, 1977) のポジティ ブ感情下位尺度（たとえば, Moskowitz, 2003）な ぞ数多くあるが，その使用頻度の高さにおいては, PANAS (Watson et al., 1988) が群を抜いている。こ の尺度は, ポジティブとネガティブ感情を, 各 10 語の形容詞を用い， 5 件法（非常にわずかか, まったくない〜非常によく) で回答し, 今 (present moment), 今日, ここ数日, ここ 1 週間, こ こ数週間, ここ 1 年, 通常の各時間範囲での回答 が可能になっている，標準化については，信頼性 と妥当性（併存的妥当性）が確認され, 広く研究 に耐えうる尺度になっている。この尺度の適用は かなり柔軟に行われていて，たとえば，標準化過 程では扱われなかった「ここ 2 週間」という教示 での使用などが頻繁にみられ（たとえば， Fredrickson \& Joiner, 2002; Pettit et al., 2001), 適用 時間範囲はかなりの可塑性をむって実施されてい る.なお,この PANASについては, 子どあ版（4 年生から 8 年生) む作成されているが (Laurent, Catanzaro, Joiner, Rudolph, Potter, Lambert, Osborne \& Gathright, 1999), ポジティブ感情につい ての発達的研究は手薄な状況が続いている.

日本でも, 質問紙については, PANAS（佐藤・ 安田，2001）やCES-D（島・鹿野・北村・浅井, 1985）の日本語版が作成されている他, 一般感情 尺度（小川・門地・菊谷・鈴木，2000）や多次元 抑うつ不安症状尺度（佐藤・安田・児玉, 2001) にポジティブ感情を測定する下位尺度が含まれて
いる. しかし, 後述するように, 文化差の指摘な ど，アメリカでの知見と比較できる知見をむたら す尺度にはなっていないことが指摘される。つま り，両国で開発された尺度による得点が，同じ概 念を同程度に測っていることを保証しない状況に ある。

ポジティブ感情を測定する方法は他にも散見さ れ, 記述された文章から, 評定者がポジティブ感 情を表す単語や文を数えたり (Danner, Snowdon \& Friesen, 2001), 小型の情報端末を利用したオンラ イン研究では, 複数の形容詞にリカート方式で回 答するという方法も採用されている (Scollon, Diener, Oishi \& Biswas-Diener, 2004). この情報端末 などを利用した方法では, 測定の精度は劣るもの の，連続した日の決まった時間にデータをとるこ とができるという意味では質問紙とは異なった情 報を得ることができ, 研究目的に合わせた使い分 けが想定される。しかし，アメリカなどでの測定 状況をみると, 測定精度についての扱いは甘く, 標準化済みの質問紙の教示や書式を自由に变えた り，複数の質問紙を実施順序などを考慮すること なく実施し，またその実施順序の記述は論文には 見あたらない場合がほとんどである。さらには， 尺度の妥当性について考慮されない場合が多く, $\alpha$ 係数などの信頼性の確認に終わっている質問紙 が少なくない，測定の精度は研究の価值の多くを 決定することから考えると, 測定方法の精度につ いての評価態度を厳しく設定することが必要であ ろう。

\section{3. ポジティブ感情の影響と機能}

ポジティブ感情の研究が集中的に実施される前 の研究をみると, ポジティブ感情については好ま しい影響が指摘されない場合む多い。たとえば, ポジティブ感情は, 注意を低下させ, 浅い情報処 理をむたらすことが指摘されている (Aspinwall, 1998; Fredrickson, 1998 のレビューを参照).これ は，ポジティブ感情が，すべてが順調であるとい 
う安全信号を意味し, 環境への注意は必要なく, 負の情報などはこのポジティブ感情を損なうとい うことから避けられる傾向をあつことが，その理 由として考えられる (Aspinwall, 1998). 認知や情 報処理の観点からさらに詳しく述べると，ポジ ティブ感情が高まっている者は, 普段から頻度高 く使用している方略や基準をもって自動的に情報 を認知したり処理したりすることが多い。この点 では, ネガティブ感情が, 問題への注意を高め, 詳細で注意深い認知や処理を追求することとは対 照的である (Park \& Banaji, 2000)．ポジティブ感情 が報酬を過大評価し，リスクを過小評価するとい う指摘も (Schwarz \& Bohner, 1996), ポジティブ 感情のこれらの特徵から派生している可能性があ り, 正確な認知と情報処理を歪めている.

しかしながら，近年のポジティブ感情にかかわ る研究は, 認知や情報処理の領域を含めて, ポジ ティブ感情が想像以上に多様な恩恵をもたらすこ とを明らかにしつつある。

\section{（1）情報処理過程（注意, 認知, 記憶, 期待) への影響}

ポジティブ感情の高まっている者は, ネガティ ブ感情や中性的な感情状態にある者とは異なった 認知や情報処理特徵をむつことが指摘されてきた が，その特徽はマイナス面よりもプラス面の色彩 が濃い。一般に, ポジティブ感情は, 刺激項目の 類似性への注意や認知を高めることが指摘され, あるカテゴリーには通常含まれない項目について あ, 類似性をとらえて柔軟に範疇化する傾向があ る（たとえば, Isen et al., 1992; Kahn \& Isen, 1993). そしてこの傾向は，ポジティブ感情状態にある者 は情報をよりうまく統合するという特徽 (Estrada et al., 1997) とも関係している. 他方, 刺激項目の 違いに注目することが求められると, ポジティブ 感情の高まった者はそうでない者より，より多く の違いをとらえることも指摘されている（たとえ ば, Murray, Sujan, Hirt \& Sujan, 1990). 総合する と, ポジティブ感情は, 刺激の類似性と違いを同
時にとらえることができるという長所ばかりが強 調されるが (Isen, 2000), 一般には, ネガティブ感 情は, 注意を狭め, 局所的な認知や処理を高める が，ポジティブ感情は，注意を広め，全体的な認 知や処理を高める (Fredrickson \& Branigan, 2005).

また，ポジティブ感情は記憶でのポジティブ事 象への接近を容易にし, その事象の派生事象への 接近範囲も広げる（たとえば, Isen, Johnson, Mertz \& Robinson, 1985; Teasdale \& Fogarty, 1979). この記憶特徵は認知にも反映され, 比較的中性的 な刺激についてもポジティブな側面への認知を高 める. たとえば，ポジティブ感情状態にある者は, そうでない者より, 中性スライドをより快的であ ると評定し (Isen \& Shalker, 1982), 曖昧な表情を より好意的にとらえる (Schiffenbauer, 1974). ポ ジティブ感情が高まった者の期待特徴もそうでな い者と比べると特徵的で, ギャンブルのように遂 行と報酬の関係が極めて低い場合は, ポジティブ 感情は遂行と報酬の結びつきへの期待をコント ロール条件と比べて高めることはないが，その関 係が高い場合は, 期待をより高める (Erez \& Isen, 2002). すなわち, ポジティブ感情は, まわりの事 象のすべてをバラ色にみるというょりも, その可 能性がある場合にそのように認知するという傾向 が一般に指摘される.

上述の特徴は, 刺激や情報の入力にかかわる特 徵であるが, 出力を考慮した研究をみても, ポジ ティブ感情の恩恵が指摘されている. ポジティブ 感情状態にある者は, 物事の決定において効率が よく, コントロール条件の者と比べて, 時間をと らないし，探索に咒長さがなく，重要でない次元 の情報を除外する (Isen \& Means, 1983). たとえ ば, Estrada et al. (1997) では, 内科医を対象にし た研究で, 肝臓疾患をむつ患者の診断過程を調 べ，ポジティブ感情状態にある内科医の方が，コ ントロール条件の内科医よりも, より早く診断を 行ったことが報告されている.

このようなポジティブ感情の恩恵をみると, ポ 
ジティブ感情の 1 つのマイナス点を指摘する過去 の一連の研究と最近の研究との齟䶣についてふれ る必要がある。そのマイナス点は, ポジティブ感 情が高まっている者は, 自分にとってネガティブ な情報を避ける傾向があるという指摘である（た とえば, Wegener \& Petty, 1994). しかしながら, 最近の研究では, 確かにネガティブな情報が自分 にとっての関連性や重要性が低い場合には避けら れる傾向があるが，この情報が自分にとって関連 性が高い場合, たとえば, ネガティブ情報を処理 することが必要な事態や，長期的な観点からはそ の処理に恩恵があるような場合は, ポジティブ感 情の高まった者は，ネガティブな材料や問題ある 事態にであ入念な対処を行うことが報告されてい る（たとえば, Aspinwall \& Taylor, 1997; Trope \& Pomerantz, 1998). 他の研究でも, 自分にとって 実質的なリスクをもたらすような事態では，その リスクに積極的に向かうことが報告されている （たとえば, Arkes, Herren \& Isen, 1988).また， Trope らの研究 (Trope \& Neter, 1994; Trope \& Pomerantz, 1998) では, 中性あるいはネガティブ な感情状態にある者よりも，ポジティブ感情状態 にある者の方が, 自分たちの利点に関する情報よ りも弱点に関する情報により興味をむつと報告さ れている.

こうした最近の研究より, Isen (1993) は, ポジ ティブ感情は, ネガティブな情報の重要度が低く, それを避けることに利点があるとみなされる場合 は，ネガティブ情報を避ける傾向があることを指 摘し，ネガティブ情報が重要で実質的な損失をも たらすような特徵をむつ場合は，ネガティブ情報 を処理する認知的な努力を高めることを指摘して いる．このような解釈から，ポジティブ感情がネ ガティブ情報に対する処理を低めるという過去の 研究は, ネガティブ情報の重要度が低く, その情 報が目標とのかかわりがほとんどない条件で提示 されていたということになる.

\section{（2）コーピングへの影響}

上述した認知特徵や情報処理特徵をもたらすポ ジティブ感情は, ストレスや逆境場面でのコーピ ングとも大きな関連をもっている。たとえば, Folkman とその共同研究者は, AIDS の看護者につ いての縦断的研究で, 次の 3 つのコーピングがポ ジティブ感情の生起や維持と関連してしているこ とを明らかにしている (Folkman, Moskowitz, Ozer \& Park, 1997; Moskowitz, Folkman, Collette \& Vittinghoff, 1996). すなわち, 前むきな正の再評価 (positive reappraisal), 目標指向的な問題焦点型 コーピング (goal-directed problem-focused coping), そして日常の出来事へのポジティブな意味 の付加 (infusion of ordinary events with positive meaning) であり, さらに Folkman (1997) は, こ れらに宗教的な信念と実践 (spiritual beliefs and practice) を加えている.

Folkman (1997) は, コーピング過程に関する彼 女の修正モデルで，ポジティブ感情とこれら 4 つ のコーピングを組み込み, このコーピングがポジ ティブ感情をむたらし, 逆にポジティブ感情はこ れらのコーピングを維持することを示唆している. 彼女のモデルでは，ポジティブ感情から 4 つの コーピング方略への因果関係は明示されていない が，この方向での因果関係については, Fredrickson \& Joiner (2002) が縦断的研究において, ポジ ティブ感情が, 認知を広めるコーピング方略と考 えられる認知的分析 (cognitive analysis: 問題に対 処するため違った方向から考える等）をもたらし， 同時にこのコーピングがポジティブ感情をもたら すという，相互の因果関係を明らかにしている。

コーピングの 2 大別は, 問題焦点型 (problemfocused) と情動焦点型 (emotion-focused) のコー ピングである（たとえば，Folkman \& Lazarus, 1980)。そして，たとえば，佐々木・山崎 (2002) では, Tobin, Holroyd, Reynolds \& Wigal (1989) の 研究を参照し, 問題焦点型に, 問題解決 (problem solving) と認知的再解釈 (coginitive reinterpre- 
tation), 情動焦点型に, 情動表出 (emotion expression) と情緒的サポート希求 (emotional support seeking) の下位構成を想定し, 標準化度の高 い尺度も開発している。この分類に従えば，これ までの研究で, ポジティブ感情との関連が指摘さ れているのは, 主として問題解決と認知的再解釈 であると考えられ, 情動焦点型との直接的な関連 を示す研究は見あたらない. ただ, Keltner \& Bonanno (1997) は，デュシャンヌ微笑を示す者が他 者からいたわりを受けやすいことを示している. この微笑により確認されるポジティブ感情の生起 が，他者からのサポートを受けやすくすることを この研究は示している。このポジティブ感情によ るサポート受容の経験から, ポジティブ感情生起 時にサポートを求めやすくなる（情緒的サポート 希求）という関連屯推測される。しかしながら， この関連について，質問紙など客観的な尺度を用 いた研究は皆無である.

この点については, 最近, Yamasaki \& Uchida (2005) は，この領域のこれまでの研究が男女差を 考慮せず実施されてきたことを批判し, 問題焦点 型と情動焦点型のコーピングを測定する尺度を用 いてポジティブ感情との関係を調べている．その 結果, 問題焦点型とポジティブ感情の正の関連は 男性に限って見られること, そして, 情動焦点型 の 1 つである感情表出とポジティブ感情の正の関 連が女性に限って見られることを示し，明確な男 女差や感情表出とポジティブ感情の関連など，こ の領域に新しい知見をもたらしている。ポジティ ブ感情とコーピングの関連についての研究領域の みならず，ポジティブ感情の研究領域では一般に 性の要因が無視されることが多いが, 感情の特徵 には大きな性差があることが予想され，今後この 領域の研究では性別の分析は必須となろう。

\section{(3) 対人関係への影響}

一般に，ポジティブ感情は外向性と正に関連し （たとえば，Lucas \& Baird, 2004)，このことから， ポジティブ感情の高い者が社交的になり，対人関
係の良好な側面を促進することが推測される，以 下に，ポジティブ感情と対人関係の関連を扱った 過去の研究知見を列挙すると, まず, 対人交渉場 面で, ポジティブ感情状態にある者は, 攻撃的な 方略を用いることが少なく，その交渉を楽しむ (Carnevale \& Isen, 1986). また, ポジティブ感情 の高まった者は, 他者の観点からものを見る傾向 を高め (Isen, 2000), 他者を援助する傾向がある (Isen, 1987, 2000) ことが示唆されている.さらに, 特定の職業を対象とした研究では, 医者の診断に 屯影響し，ポジティブ感情の高い医者は, 外発的 な動機づけ（金銭や地位）よりも内発的な動機づ け（人道的立場）による診断に満足を覚えること が多いことも指摘されている (Estrada et al., 1997). こうして，これまでの多くの研究が，全般的にポ ジティブ感情は, 他者への援助, 寛大さ, 責任感 の強さ, 親しみやすさ, 社交性などを促進するこ とを示している（レビューとして, Isen, 1987 を参 照のこと).

さらに，グループを対象とした研究でも，Dovidio, Gaertner, Isen \& Lowrance (1995) は, ポジ ティブ感情はグループ間の区別を減じ，他のグ ループメンバーを自分のグループメンバーとして 扱う傾向が高いことを示唆している.グループ間 の区別は，グループについてのステレオタイプ的 な基準にもとづくことが多いが，この研究は，ポ ジティブ感情がその基準にもとづく傾向を低める ことを示している。この点は, ポジティブ感情が グループについてのステレオタイプ的な基準を採 用する傾向を強めることを示した Park \& Banaji (2000) の知見とは反し，この研究知見の違いをむ たらす原因は不明である。 ネガティブ情報への処 理過程に見られたのと同様に, 条件に依存した違 いが見られる可能性もあり, 今後の研究はこの点 を明らかにする必要がある。

\section{（4）身体と健康への影響}

ポジティブ感情とコーピングの関連は上述した 通りであるが，ポジティブ感情がストレスへの 
コーピングを促進する以上，健康全般へ良好な結 果をもたらすことが予想される。ここでは，この 問題をほぼ身体的な側面に限定して概説したい.

Fredrickson らは，ポジティブ感情の回復効果 (undoing effect) を仮説している(Fredrickson et al., 2000; Tugade \& Fredrickson, 2004). この効果は, ネガティブな事象によってもたらされた生理反応 の昂進（たとえば心拍率の上昇）がポジティブ感 情によってもとの状態によりはやく回復するとい う現象を指している。 たとえば, Fredrickson et al. (2000) では, 不安により心臓血管系の反応を昂進 し, その後, 特定の感情を喚起するフィルムを見 せて心臓血管反応を測定したところ, 満足 (contentment) を喚起するフィルムと愉快な (amusing) フィルムを見せた場合, 中性あるいは悲しいフィ ルムより心臓血管系反応のはやい回復を示した。 長時間, 長期にわたる生理的反応の昂進は健康面 に悪影響を与えることから，この効果の意義は大 きい. ポジティブ感情と生理的反応の関係を調べ た研究は免疫系の反応であ見られ, 愉快なビデオ を見た参加者は免疫の機能が高まる (Lefcourt, Davidson-Katz \& Kuenemen, 1990). また, 日常の あめ事の中での気分の高揚 (uplift) の経験はガン の既往歴のある者のナチュラル・キラー細胞の活 動の高まりと関連し, このナチュラル・キラー細 胞水準の高まりは, 日常場面で生まれるポジティ ブ感情とも正に関連していることが報告されてい る (Valdimarsdottir \& Bovbjerg, 1997).

ポジティブ感情と健康との正の関連は, 行動面 や自己報告に打いても確認され，ポジティブ感情 が高く, ネガティブ感情が低い者は, 健康である との主観的報告の度合いが高く（たとえば，Pettit et al., 2001), 身体的症状の報告の度合い屯低い (Billings, Folkman, Acree \& Moskowitz, 2000; Watson, 1988). また, 行動面では, ポジティブ感情 は, 諸々の疾患予防的ならびに健康増進的行動之 結びっいている。たとえば，ポジティブ感情は高 い運動水準と関連し (Lox, Burns, Treasure \&
Wasley, 1999), 喫煙の研究でも, ポジティブ感情 は，喫煙への衝動と負に関連していることが示さ れている (Zinser, Baker, Sherman \& Cannon, 1992). この健康行動との関連は, 薬物使用において屯認 められ，1,700名を超える青少年の縦断的研究で は, ポジティブ感情がネガティブ感情と薬物使用 の関連に干渉することが示されている (Wills, Sandy, Shinar \& Yaeger, 1999). このようなポジティ ブ感情と健康との関連から予想されることではあ るが, Danner et al. (2001) は, カソリックの修道 女が書いた自伝にみられるポジティブ感情と寿命 とに正の関連を見いだし，ポジティブ感情の表現 が少ない者に比べて多い者は平均して 10 年長く 生存し，ポジティブ感情が寿命を延ばすことにも つながることを示唆している.

また, 実際に病的状態や極度のストレス状態に ある者を対象にした研究に扔いて, ポジティブ感 情が病状の進行を鈍らせ, 改善をむもたらし, ス トレスからの悪影響を緩和するという報告む少な くない。たとえば，Moskowitz (2003)は，ポジ ティブ感情の高い AIDS 患者はポジティブ感情が 平均あるいは低い AIDS 患者よりも有意に死亡率 が低いことを示している。 また, AIDS 患者と死別 した世話人 (Moskowitz, 2001) のストレスやSeptember 11 のテロ後のストレス (Fredrickson, Tugade, Waugh \& Larkin, 2003) をポジティブ感情の 生起が緩和するという干渉効果も明確に示されて いる.

ストレスは精神面の健康にもかかわるが, 本論 文では抑うつなど精神的健康との関連を削除した。 その理由は, 感情状態自体が精神的影響を反映す ることが多いからで, 感情とは概念上独立して精 神的健康に言及することが難しいことにあった。 しかし, 日常の起伏を伴う状態的な感情は, 必ず しも精神的健康との関連は自明ではなく, 共通要 素を考慮しながら慎重に研究を進めることは可能 であろう。これまでの研究はこの点を考慮せず, あともとある共通要素から過剩な関連性を引き出 
しているものが多い.この点へ細心の注意をすれ ば，今後，身体と精神両面の健康を同時に考慮し てポジティブ感情の研究を進めることが可能とな り, この方向の研究はこれまでの研究には欠けて いた点である。また，同じ健康指標でも，疾患そ のもの, 健康行動, そして生理的反応は, ポシ ティブ感情の同じ従属变数というょりも, それら 自体にも因果の関係が予測される。たとえば，ポ ジティブ感情が運動などの健康習慣を高め，その 結果健康が増進されるという類の媒介効果が考え られ, このような, 健康関連従属变数のポジティ ブ感情への段階的な関係を調べることも今後の研 究の重要な課題となろう.

ポジティブ感情がもたらす恩恵については, 他 にも，仕事における満足度，収入の増大，失業率 （たとえば, Diener, Nickerson, Lucas \& Sandvik, 2002）, 奉仕活動への参加の高まり（たとえば, Magen \& Aharoni, 1991）など, 現実社会への具体 的な成果や貢献に関連した研究も多数確認される が，その多くの研究が状態よりも特性的なポジ ティブ感情を扱っているので本論文では割愛した い.

\section{4. ポジティブ感情の影響にかかわる メカニズム}

先述のように，ポジティブ感情は多面にわたっ て好結果をむたらすが，これらの現象を，すべて ではないにしても，ある程度包括的に説明できる ような見解がこれまでに提示されている。本節で は, ポジティブ感情の役割を導く心理学的メカニ ズムとしていくつかの仮説を紹介したい.

\section{(1) Carver らの仮説}

Carver ら (Carver, 2003; Carver \& Scheier, 1998) は一つのフィードバック・システムを仮説し，そ れは，接近や回避行動だけをモニターするのでは なく, その行動の時間の経過に伴う効果をモ二 夕ーする.そのシステムでは, 行動の効果が入力 され，設定された基準と比較される．基準よりあ
行動の効果が低ければネガティブ感情が生じ, 高 ければポジティブ感情が生じ, 基準と変わらなけ れば感情は生じない。 また, 誘因への接近の成功 と脅威の回避の成功は同じではなく, 異なったポ ジティブ感情を生み, このことはネガティブ感情 についても同様である.

こうしたモデルの中, ポジティブ感情は, ネガ ティブな事象が消失したときネガティブ感情にか わって生起するという側面が強調され，このポジ ティブ感情の生起は, その生起直前までのネガ ティブ事象や挑戦的な事象 (challenging event) か ら人を離し, 将来起こる可能性がある問題への準 備段階をむたらすという。この準備段階により, ポジティブ感情状態にある人は, 浅いけれどあ広 く情報を探索し, 問題の発生の同定とその対処準 備に入る。これは，ネガティブ感情が，限定的か つ集中的に，直面しているネガティブ事象に対処 するのとは対照的な機能である．この Carverの見 解は，「森を見て，木を見ない」という，ポジティ ブ感情がもたらす注意や認知の全般的な特徽の根 拠を示している. ポジティブ感情状態にある者は, 自分への重要度が高い情報であれば，ネガティブ 情報にもより高い注意を向けて処理するという結 果む, 将来への準備という Carver らの見解からは 解釈可能であろう.

\section{(2) Fredrickson らの仮説}

Fredrickson（たとえば, Fredrickson, 1998, 2001） は, ポジティブ感情の拡大一構築理論 (broadenand-build theory) を提起している.この理論では, ポジティブ感情は, その時々の思考一行動レパー

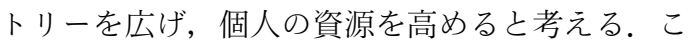
こでの思考一行動レパートリーは, 注意, 認知, 行為，思考のレパートリーを指し，個人の資源は， 身体的資源（たとえば，健康や寿命), 社会的資 源（たとえば，友達関係やソーシャル・サポー 卜), 知的資源（たとえば，専門的知識や知的複 雑性), 心理的資源（たとえば，レジリエンス 〔resilience〕や楽観主義）などを含んでいる。 
Fredrickson et al. (2003) は，ポジティブ感情が, 一般にはみられない思考パターンを生み出し (Isen et al., 1985), 可塑性があり (Isen \& Daubman, 1984), 創造的 (Isen, Daubman \& Nowicki, 1987), 統合的 (Isen, Rosenzweig \& Young, 1991), 情報を 柔軟に取り入れる (Estrada et al., 1997), 効率がよ い (Isen \& Means, 1983; Isen et al., 1991), さらに は, ポジティブ感情が選択の広がりへの好みを生 み出し, 選択可能な行動オプションを広める (Kahn \& Isen, 1993) ことなどを, 思考一行動レ パートリーの拡大の現象として指摘している. ま た，Fredrickson ら自身も（たとえば，Fredrickson \& Branigan, 2005), 視覚刺激の類似性判断課題な ごを用いて, ポジティブ感情状態にある者が，ネ ガティブ感情や中性状態にある者よりあ, 全体的 な刺激布置に注意を向けることを明らかにし, 思 考の拡張を示すデー夕を提示している.さらに, ポジティブ感情が思考一行動レパートリーの広が りをむたらすメカニズム自体む, 喜び (joy), 興味 (interest), 満足 (contentment), 誇り (pride), 愛 (love) の各ポジティブ感情について仮説されてい

る (Fredrickson, 2001 を参照のこと).

また, Fredrickson らは（たとえば, Fredrickson \& Joiner, 2002), ポジティブ感情をたらす思考一 行動レパートリーの広がりは, ストレスや逆境事 態でのコーピングを促進し，このコーピングがさ らにポジティブ感情を生み出すという螺旋状発展 (triggering upward spirals) の過程を想定し，この サイクルの中で, 人は心理的なレジリエンスを確 立し, ウェルビーイング (well-beging) を高めると 考えている.

\section{（3）その他の見解と今後の発展}

さらに, 既存のデー夕を包括的に説明する見解 ではないが，ポジティブ感情はそれが一度生起す ると，その感情を保持する方向で機能することが 示唆されている.たとえば, ポジティブ感情を喚 起された者は, 見知ら妖を援助するという課題 が自分たちの抑うつ気分を高めるような課題であ
ると，コントロール・グループに比べて援助する ことが少ないことを示唆する研究が見受けられる (Isen \& Simmonds, 1978). ポジティブ感情状態に ある者は, 何らかの危険性を孕んだ事態が実際上 の損失をむたらす可能性があると判断すると、コ ントロール条件の者よりもその危険を避ける傾向 が高まり, その可能性がないと判断すると, コン トロール条件の者よりもその危険に関与するとい うことになる (Arkes et al., 1988). このポジティブ 感情の特徵は, これまでのポジティブ感情に関す る認知面のデー夕を直接説明することはできない が，ポジティブ感情の機能を考える場合，考慮す る必要がある一側面を示している.

Carver らの見解は, 正負感情と行動（接近, 回 避）との関係を包括的にとらえたものであり，ポ ジティブ感情に限定された見解ではないという点 でポジティブ感情にかかわる研究結果を直接的に 説明するものではない. Carver (2003) は, 既存の ポジティブ感情にかかわる知見が自分たちの仮説 から推測できることを多方面からの考察をむって 説いているが，その考察の証明は今後の実証的な 研究を待つ必要がある。ただ, 彼自身む主張して いるように, Carver らの仮説は Fredrickson らの 仮説と比較するとより節約的 (parsimonious) で, 両仮説のデータ予測性に差異がなければ，節約的 な仮説に一日の長がある。しかし, 現段階では, ポジティブ感情に限定した Fredirickson らの仮説 の方がポジティブ感情にかかわる諸々のデータと の関連が高く, ポジティブ感情に関する恩恵を理 解するには最も有効な仮説になる。ただ, 拡大一 構築理論の直接的な検証デー夕は少なく, まだ 1 つの仮説であるという域を出ていない観がある. 言い換えれば，ポジティブ感情の機能に関する仮 説はこれで十分という結論に達しているわけでは ない. ポジティブ感情の維持傾向に関する知見な ど，ポジティブ感情の役割を支えるポジティブ感 情の特徵は多様性をむつことが予想され，今後は， より包括的に既存のデー夕を説明し，かつ節約的 
な仮説の構築を模索し続ける必要がある.

また，ポジティブ感情とネガティブ感情の関係 は対称ではないが (Folkman, 1997; Pettit et al., 2001), 両者はまったくの非対称というよりも，そ の機能において互いに補足的な関係にあることも 事実である。たとえば，限定的な注意と拡散的な 注意は直面する状況により使い分ける必要があり, その使い分けはポジティブ感情とネガティブ感情 が見事に達成してくれる。つまり，現行のポジ ティブ心理学への批判にああるように，ポジとネ ガの両面を考慮したモデルこそが, 真にポジティ ブ感情の機能を明示する可能性が高いことも視野 に入れたい.

\section{5. 今後の研究一介入と文化差}

\section{(1) 介入研究}

最後に，本論文を閉じるにあたり，介入研究と 文化差について言及したい。これらは，その重要 度の高さに屯かかわらず，これまでの研究におい て手薄であった研究領域で, 今後の研究として指 摘しておく必要がある.

ポジティブ感情が多くの恩恵をむたらすことを 明らかにしてきた研究においては，ひとつの最終 目標は，そこでの知見を生かして，健康でウェ ル・ビーイングに満ちた生活へ積極的に誘うこと であろう。ここに, 介入研究の必要が生まれる。 心理学の基礎研究領域の多くが間接的にせよこの 目標にかかわっているにもかかわらず，介入とい う応用研究になると, その研究量と質が格段と落 ちることが一般にみられる。それは，介入研究が， 時間的にも経済的にも多大な投資を必要とするか らであろう。また，充実した基礎研究での知見と 乘離した介入研究も少なくない.

最近, Seligman (2002b) は，人を幸福に導く 24 ほどの長所 (human strength) を列挙している。こ のような長所をその詳細な定義や測定方法ととも に列挙することは，その長所の定量化と育成の試 みを可能にする。しかし，残念ながら，各長所の
導出過程やまたそれを測定する尺度の精度に科学 性はほとんど見られない。 介入研究に直結するよ うな基礎研究は, ある程度の科学性の欠落や精度 の低下はやむを得ないとみる向きがある、筆者も この傾向を否定する立場にはなく，むしろ，その 問題性を指摘するよりも, 介入研究の推進のため に数少ないその基盤研究を擁護する立場にある. ただ，基礎研究と応用介入研究とが大きく乘離す ることや，応用研究の基盤となる基礎研究のある 程度の科学性は保証したい。

Fredrickson (2000) は，これまでの健康や適応を むたらそうとする多くの技法が，ポジティブ感情 を介していることを示唆している。また，Toole, Bowman, Thomason, Hagopian \& Rush (2003) は, 破壊的行動を減じる行動的治療において, その改 善とともにポジティブ感情が増大したという知見 を提示した。因果関係は明確でないものの，この 研究はこの種の治療におけるポジティブ感情の重 要性を示唆している.さらに，ポジティブ感情が コーピングを促進する知見は，この感情を高める ことが，コーピングを介して健康や適応を達成で きる方向を示している。他には健康面以外でも, ポジティブ感情の認知や情報処理への好影響から, 学習や知的発達の側面でポジティブ感情の介入効 果が期待されることも示唆される.

これまでの介入研究の多くは, 認知, 感情, 行 動のネガティブな側面を変容させることに焦点が 当てられてきたが，同時にポジティブな側面を育 成するという研究も必要である. 個人の適応を達 成するために，ポジティブな経験を想起する試み は臨床場面でよく実施されているが（たとえば, Kaufman \& Raphael, 1991), 今後は, ポジティブ 感情における基礎研究の知見を生かしてこの種の 介入を積極的に開発, 実施することが期待される. また，本論文では随所に強調されてきたことでは あるが，ネガティブとポジティブの両側面を常に 考慮に入れた研究が重要で, このことは特に介入 研究においてあてはまることを最後に指摘してお 
きたい.

\section{(2) 文化差}

これまで本論文では，測定方法を除き，日本で の研究にふれることはなかった。その理由は, 本 論文の主題であるポジティブ感情の機能やそのメ カニズムに関する研究が日本ではほとんど実施さ れていないことによる。このことから，ポジティ ブ感情の機能に関して, 日本とアメリカの違い等 の，文化差にかわわる言及すべきデー夕はない.

しかしながら, 感情の体験や表出の文化差は大 きい（たとえば, Diener, Diener \& Diener, 1995; Kiyatayam, Markus, \& Kurokawa, 2000). ポジティ ブ感情に限定しても，たとえば Scollon et al. (2004) では, 誇り (pride) などの感情が日本人で は低くなることを示している。この文化差の問題 は, アメリカ主導で行われている心理学的研究, 特に性格や感情といった高次の变数を扱う研究の 取り扱いの難しさを示唆している。つまり, アメ リカ人を対象にした研究結果はアメリカ人にしか 適用できない可能性がある。アメリカで実施され る研究では, このことを意識した研究は少ない。 他方, 日本で行われる性格や感情の研究は, この 文化差が意識されることが多く, 多数の研究が考 察の最後に文化差の問題を指摘していることから あそのことが理解できる.

文化差の研究は, 測定尺度の共通化の達成がむ ずかしく, 精度の高い研究の実施がきわめて困難 な状況にある。つまり, 日本においては, アメリ 力の研究と直接比較ができる尺度がない. アメリ カでもっとも頻繁に使用されているポジティブ感 情の測定法は PANAS であるが，この PANAS の日 本版（佐藤・安田，2001）をみても, 項目構成や 回答方法が大きく違い, 両国の PANAS 得点の直 接的な比較はむずかしい. Yamasaki, Sakai \& Uchida (2006) は, 日本版 PANAS を用いて, ポジ ティブ感情とネガティブ感情に低いが有意な正の 相関を見いだし，アメリカにおける負あるいは無 相関の研究（たとえば, Pettit et al., 2001; Watson et al., 1988）と比較して, 文化差の可能性の 1つ をここに示唆している。しかし，それも，尺度の 違いという問題を越えて強く主張できる知見とは なり得ない状況である。この現状をみると, 質問 紙のみならず, 実験等の研究も駆使しながらデー 夕が蓄積されたときにはじめて文化差に言及でき るという，㛜しい見方も必要であろう。

文化差の研究は, それぞれの文化固有の研究に 加えてさらに精力的に実施する必要がある。それ と同時に, 研究数が他国を圧倒するアメリカにお けるこの領域の心理学的研究においては, その知 見は, アメリカ人にしか適用できないという可能 性に鋭敏になる必要があることを強調しておきた w.

\section{引用文献}

Arkes, H. R., Herren, L. T., \& Isen, A. M. 1988 Role of possible loss in the influence of positive affect on risk-taking behavior. Organizational Behavior and Human Decision Processes, 42, 181-193.

Aspinwall, L. G. 1998 Rethinking the role of positive affect in self-regulation. Motivation and Emotion, 22, $1-32$.

Aspinwall, L. G., \& Taylor, S. E. 1997 A stitch in time: Selfregulation and proactive coping. Psychological Bulletin, 121, 417-436.

Billings, D. W., Folkman, S., Acree, M., \& Moskowitz, J. T. 2000 Coping and physical health during caregiving: The roles of positive and negative affect. Journal of Personality and Social Psychology, 79, 131-142.

Bradburn, N. 1969 Psychological well-being. Chicago: Aldine.

Carnevale, P. J. D., \& Isen, A. M. 1986 The influence of positive affect and visual access on the discovery of integrative solutions in bilateral negotiation. Organizational Behavior and Human Decision Processes, 37, $1-13$.

Carver, C. S. 2003 Pleasure as a sign you can attend to something else: Placing positive feelings within a general model. Cognition and Emotion, 17, 241-261.

Carver, C. S., \& Scheier, M. F 1998 On the self-regulation of behavior. New York: Cambridge University Press.

Danner, D. D., Snowdon, D. A., \& Friesen, W. V. 2001 Posi- 
tive emotions in early life and longevity: Findings from the nun study. Journal of Personality and Social Psychology, 80, 804-813.

Diener, E., Diener, M., \& Diener, C. 1995 Factors predicting the subjective well-being of nations. Journal of Personality and Social Psychology, 69, 851-864.

Diener, E., \& Emmons, R. A. 1984 The independence of positive and negative affect. Journal of Personaltiy and Social Psychology, 47, 580-592.

Diener, E., Nickerson, C., Lucas, R. E., \& Sandvik, E. 2002 Dispositional affect and job outcomes. Social Indicators Research, 59, 229-259.

Diener, E., Smith, H., \& Fujita, F. 1995 The personality structure of affect. Journal of Personality and Social Psychology, 69, 130-141.

Dovidio, J. F., Gaertner, S. L., Isen, A. M., \& Lowrance, R. 1995 Group representations and intergroup bias: Positive affect, similarity, and group size. Personality and Social Psychology Bulletin, 21, 856-865.

Erber, R., Wegner, D. M., \& Therriault, N. 1996 On being cool and collected: Mood regulation in anticipation of social interaction. Journal of Personality and Social Psychology, 70, 757-766.

Erez, A., \& Isen, A. M. 2002 The influence of positive affect on the components of expectancy motivation. Journal of Applied Psychology, 87, 1055-1067.

Estrada, C. A., Isen, A. M., \& Young, M. J. 1997 Positive affect facilitates integration of information and decrease anchoring in reasoning among physicians. Organizational Behavior and Human Decision Processes, 72, 117-135.

Folkman, S. 1997 Positive psychological states and coping with severe stress. Social Science and Medicine, $\mathbf{4 5}$, 1207-1221.

Folkman, S., \& Lazarus, R. S. 1980 An analysis of coping in a middle-aged community sample. Journal of Health and Social Behavior, 21, 219-239.

Folkman, S., Moskowitz, J. T., Ozer, E. M., \& Park, C. L. 1997 Positive meaningful events as coping in the context of HIV/AIDS. In B. H. Gottlieb (Ed.), Coping with chronic stress. New York: Plenum. Pp. 293-314.

Fredrickson, B. L. 1998 What good are positive emotions? Review of General Psychology, 2, 300-319.

Fredrickson, B. L. 2000 Cultivating positive emotions to optimize health and well-being. Prevention and Treatment, 3, Article 0001a.
Fredrickson, B. L. 2001 The role of positive emotions in positive psychology: The broaden-and-build theory of psositive emotions. American Psychologist, 56, 218226.

Fredrickson, B. L. 2003 The value of positive emotions: The emerging science of positive psychology is coming to understand why it's good to feel good. American Scientist, 91, 330-335.

Fredrickson, B.L., \& Branigan, C. 2005 Positive emotions broaden the scope of attention and thought-action repertoires. Cognition and Emotion, 19, 313-332.

Fredrickson, B. L., \& Joiner, T. 2002 Positive emotions trigger upward spirals toward emotional well-being. Psychological Science, 13, 172-175.

Fredrickson, B. L., \& Levenson, R. W. 1998 Positive emotions speed recovery from the cardiovascular sequelae of negative emotions. Cognition and Emotion, 12, 191220.

Fredrickson, B. L., Mancuso, R. A., Branigan, C., \& Tugade, M. M. 2000 The undoing effect of positive emotions. Motivation and Emotion, 24, 237-258.

Fredrickson, B. L., Tugade, M. M., Waugh, C. E., \& Larkin, G. R. 2003 What good are positive emotions in crises? A prospective study of resilience and emotions following the terrosits attacks on the United States on September 11th, 2001. Journal of Personality and Social Psychology, 84, 365-376.

Homenover, S. H. 2003 Individual differences in rate of affect change: Studies in affective chronometry. Journal of Personality and Social Psychology, 85, 121-131.

Isen, A. M. 1987 Positive affect, cognitive processes, and social behavior. In L. Berkowitz (Ed.), Advances in experimental social psychology. Vol. 20. San Diego, CA: Academic Press. Pp. 203 -252.

Isen, A. M. 1993 Positive affect and decision making. In M. Lewis, \& J. M. Haviland (Eds.), Handbook of emotions. New York: Guilford Press. Pp. 261-277.

Isen, A. M. 2000 Positive affect and decision making. In M. Lewis, \& J. M. Haviland-Jones (Eds.), Handbook of emotions. 2nd ed. New York: Guilford Press. Pp. 417435.

Isen, A. M. 2002 A role for neuropsychology in understanding the facilitating influence of positive affect on social behavior and cognitive processes. In C.R. Snyder, \& S. J. Lopez (Eds.), Handbook of positive psychology. London: Oxford Universtiy Presss. Pp. 528-540. 
Isen, A. M., \& Daubman, K. A. 1984 The influence of affect on categorization. Journal of Personality and Social Psychology, 47, 1206-1217.

Isen, A. M., Daubman, K. A., \& Nowicki, G. P. 1987 Positive affect facilitates creative problem solving. Journal of Personality and Social Psychology, 53, 1122-1131.

Isen, A. M., Johnson, M. M. S., Mertz, E., \& Robinson, G. F. 1985 The influence of positive affect on the unusualness of word associations. Journal of Personality and Social Psychology, 48, 1413-1426.

Isen, A. M., \& Means, B. 1983 The influence of positive affect on decision-making strategy. Social Cognition, 2, 18-31.

Isen, A. M., Niedenthal, P. M., \& Cantor, N. 1992 An influence of positive affect on social categorization. Motivation and Emotion, 16, 65-78.

Isen, A. M., Rosenzweig, A. S., \& Young, M. J. 1991 The influence of positive affect on clinical problem solving. Medical Decision Making, 11, 221-227.

Isen, A. M., \& Shalker, T. E. 1982 The effect of feeling state on the evaluation of positive, neutral, and negative stimuli: When you "accenuate the positive," do you "eliminate the negative"? Social Psychology Quarterly, 45, 58-63.

Isen, A. M., \& Simmonds, S. F. 1978 The effect of feeling good on a helping task that is incompatible with good mood. Social Psychology Quarterly, 41, 345-349.

Kahn, B. E., \& Isen, A. M. 1993 The influence of positive affect on variety-seeking among safe, enjoyable products. Journal of Consumer Research, 20, 257-270.

Kaufman, G., \& Raphael, L. 1991 Dynamics of power. 2nd ed. Rochester: Schenkman Books.

Keltner, D., \& Bonanno, G. A. 1997 A study of laughter and dissociation: Distinct correlates of laughter and smiling during bereavement. Journal of Personality and Social Psychology, 73, 687-702.

Kitayama, S., Markus, H. R., \& Kurokawa, M. 2000 Culture, emotion, and well-being: Good feelings in Japan and the United States. Cognition and Emotion, 14, 93-124.

Lane, R. D., Reiman, E. M., Bradley, M. M., Lang, P. J., Ahem, G. L., Davidson, R. J., \& Schwartz, G. E. 1997 Neuroanatomical correlates of pleasant and unpleasant emotion. Neuropsychologia, 35, 1437-1444.

Larsen, R. J., \& Diener, E. 1992 Promises and problems with the circumplex model of emotion. In M.S. Clark (Ed.), Review of personality and social psychology: Emo- tion. Vol. 13. Newbury Park, CA: Sage. Pp. 25-59.

Laurent, J., Catanzaro, S. J., Joiner, Jr., T. E., Rudolph, K. D., Potter, K. I., Lambert, S., Osborne, L., \& Gathright, T. 1999 A measure of positive and negative affect for children: Scale developemnt and preliminary validation. Psychological Assessment, 11, 326-338.

Lazarus, R. S. 2003 The Lazarus manifesto for positive psychology and psychology in general. Psychological Inquiry, 14, 173-189.

Lefcourt, H. M., Davidson-Katz, K., \& Kuenemen, K. 1990 Humor and immune system functioning. Humor, 3, 305-321.

Lox, C. L., Burns, S. P., Treasure, D. C., \& Wasley, D. A. 1999 Physical and psychological predictors of exercise dosage in healthy adults. Medicine and Science in Sports and Exercise, 31, 1060-1064.

Lucas, R. E., \& Baird, B. M. 2004 Extraverstion and emotional reactivity. Journal of Personality and Social Psychology, 86, 473-485.

Lucas, R. E., Diener, E., \& Larsen, R. J. 2003 Measuring positive emotions. In S. J. Lopez, \& C. R. Snyder (Eds.), Positive psychology assessment: A handbook of models and measures. Washington, DC: American Psychological Associaton. Pp. 201-218.

Magen, Z., \& Aharoni, R. 1991 Adolescents' contributing toward others: Relationship to positive experiences and transpersonal commitment. Journal of Humanistic Psychology, 31, 126-143.

Mayer, J. D., \& Gaschke, Y. N. 1988 The exprerience and meta-experience of mood. Journal of Personality and Social Psychology, 55, 102-111.

Moskowitz, J. T. 2001 Emotion and coping. In T. J. Mayne, \& G. A. Bonnano (Eds.), Emotion: Current issues and future directions. New York: Guilford Press. Pp. 311-336.

Moskowitz, J. T. 2003 Positive affect predicts lower risk of AIDS mortality. Psychosomatic Medicine, 65, 620-626.

Moskowitz, J. T., Folkman, S., Collette, L., \& Vittinghoff, E. 1996 Coping and mood during AIDS-related caregiving and bereavement. Annals of Behavioral Medicine, 18, 49-57.

Murray, N., Sujan, H., Hirt, E. R., \& Sujan, M. 1990 The influence of mood on categorization: A cognitive flexibility interpretation. Journal of Personality and Social Psychology, 59, 411-425.

小川時洋・門地里絵・菊谷麻美・鈴木直人 2000 一 般感情尺度の作成 心理学研究， 71, 241-246. 
Park, J., \& Banaji, M. R. 2000 Mood and heuristics: The influence of happy and sad states on sensitivity and bias in stereotyping. Journal of Personality and Social Psychology, 78, 1005-1023.

Pettit, J. W., Kline, J. P., Gencoz, T., Gencoz, F, \& Joiner, T. E. 2001 Are happy people healthier? The specific role of positive affect in predicting self-reported health symptoms. Journal of Research in Personality, 35, 521536.

Radloff, L. S. 1977 The CES-D scale: A self-report depression scale for research in the general population. Applied Psychological Measurement, 1, 385-401.

Russell, J. A. 1980 A circumplex model of affect. Journal of Personality and Social Psychology, 39, 1161-1178.

Russell, J. A. 2003 Core affect and the psychological construction of emotion. Psychological Review, 110, 145172.

佐々木恵・山崎勝之 2002 コーピング尺度 (GCQ) 特 性版の作成および信頼性・妥当性の検討 日本公衆衛 生雑誌, 49, 399-408.

佐藤 徳 - 安田朝子 2001 日本語版 PANAS の作成 性格心理学研究, 9, 138-139.

佐藤 徳・安田朝子・児玉千稲 20013 要因モデルに 基づく, 抑うつならびに不安症状の分類——多次元抑 うつ不安症状尺度の作成 性格心理学研究, 10 , 15-26.

Schiffenbauer, A. 1974 Effects of observer's emotional state on judgments of the emotional state of others. Journal of Personality and Social Psychology, 30, 31-36.

Schwarz, N., \& Bohner, G. 1996 Feelings and their motivational implications: Moods and the action sequence. In P. M. Gollwitzer, \& J. A. Bargh (Eds.), The psychology of action: Linking cognition and motivation to behavior. New York: Guilford Press. Pp. 119-145.

Scollon, C. N., Diener, E., Oishi, S., \& Biswas-Diener, R. 2004 Emotions across cultures and methods. Journal of Cross-Cultural Psychology, 35, 304-326.

Seligman, M. E. P. 2002a Positive psychology, positive preventin, and positive therapy. In C. R. Snyder, \& S. J. Lopez (Eds.), Handbook of positive psychology. New York: Oxford Universtiy Press. Pp. 3-9.

Seligman, M. E. P. 2002b Authentic happiness: Using the new positive psychology to realize your potential for lasting fulfilment. London: Nicholas Brealey.

Seligman, M.E.P., \& Csikszentmihalyi, M. 2000 Posotive psychology: An introduction. American Psychologist,
55, 5-14.

島 悟・鹿野達男・北村俊則・浅井昌弘 1985 新し い抑うつ性自己評定尺度について 精神医学, 27 , $717-723$.

Taylor, S. E., Dickerson, S. S., \& Klein, L. C. 2002 Toward a biology of social support. In C. R. Snyder, \& S. J. Lopez (Eds.), Handbook of positive psychology. London: Oxford Universtiy Presss. Pp. 556-569.

Teasdale, J. D., \& Fogarty, S. J. 1979 Differential effects of induced mood on retrieval of pleasant and unplesant evernts from episodic memory. Journal of Abnormal Psychology, 88, 248-257.

Terracciano, A., McCrae, R. R., Hagemann, D., \& Costa, P. T. 2003 Individual difference variable, affective differentiation, and the structures of affect. Journal of Personlality, 71, 669-703.

Tobin, D. L., Holroyd, K. A., Reynolds, R. V., \& Wigal, J. K. 1989 The hierarchical factor structure of the Coping Strategies Inventory. Cognitive Therapy and Research, 13, 343-361.

Toole, K. M., Bowman, L. G., Thomason, J. L., Hagopian, L. P., \& Rush, K. S. 2003 Observed increases in positive affect during behavioral treatment. Behavioral Interventions, 18, 35-42.

Trope, Y., \& Neter, E. 1994 Reconciling competing motives in self-evaluation: The roles of self-control in feedback seeking. Journal of Personality and Social Psychology, 66, 636-657.

Trope, Y., \& Pomerantz, E. M. 1998 Resolving conflicts among self-evaluative motives: Positive experiences as resource for overcoming defensiveness. Motivation and Emotion, 22, 53-72.

Tugade, M. M., \& Fredrickson, B. L. 2004 Resilient individuals use positive emotions to bounce back from negative emotional experiences. Journal of Personality and Social Psychology, 86, 320-333.

Valdimarsdottir, H. B., \& Bovbjerg, D. H. 1997 Positive and negative mood: Association with natural killer cell activity. Psychology and Health, 12, 319-327.

Van Yperen, N. W. 2003 On the link between different combinations of negative affectivitity (NA) and positive affectivity (PA) and job performance. Personality and Individual Differences, 35, 1873-1881.

Viney, L. L. 1986 Expression of positive emotion by people who are physically ill: Is it evidence of defending or coping? Journal of Psychosomatic Research, 30, 27-34. 
Watson, D. 1988 Intraindividual and interindividual analyses of positive and negative affect: Their relations to health complaints, perceived stress, and daily activities. Journal of Personality and Social Psychology, 54, 10201030.

Watson, D., Clark, L. A., \& Auke, T. 1998 Development and validation of brief measures of positive and negative affect: The PANAS sclaes. Journal of Personality and Social Psychology, 54, 1063-1070.

Watson, D., Wiese, D., Vaidya, J., \& Tellegen, A. 1999 The general activation systems of affect: Structural findings, evolutionary considerations, and psychobiological evidence. Journal of Personality and Social Psychology, 76, 820-838.

Wegener, D. T., \& Petty, R. E. 1994 Mood management across affective states: The hedonic contingency hypothesis. Journal of Personality and Social Psychology, 66, 1034-1048.

Wills, T. A., Sandy, J. M., Shinar, O., \& Yaeger, A. 1999 Contributions of positive and negative affect to adolescnet substance use: Test of a bidimensional model in a longitudinal study. Psychology of Addictive Behaviors, 13,
327-338.

Wortman, C. B., \& Silver, R. C. 2001 The myths of coping with loss revisited. In M. Stroebe, R. O. Hansson, W. Stroebe, \& H. Schut (Eds.), Handbook of bereavement research: Consequences, coping, and care. Washington, DC: American Psychological Association. Pp. 405-430.

Yamasaki, K., Sakai, A., \& Uchida, K. 2006 A longitudinal study of the relationship between positive affect and both problem- and emotion-focused coping strategies. Social Behavior and Personality: An International Journal, 34. (In press)

Yamasaki, K., \& Uchida, K. 2005 The relationship between positive affect and emotion-focused coping. Paper presented at the 6th Annual Meeting of the Socitey of Personality and Social Psychology, New Orleans, USA.

Zinser, M. C., Baker, T. B., Sherman, J. E., \& Cannon, D. S. 1992 Relation between self-reported affect and drug urges and cravings in continuing and withdrawing smokers. Journal of Abnormal Psychology, 101, 617629 .

- 2005.6.25 受稿, 2005.11.29 受理一

\title{
Roles of Positive Affect: The Phenomena and Mechanisms
}

\author{
Katsuyuki YAMASAKI \\ Department of Human Development, Naruto University of Education \\ The Japanese Journal of Personality 2006, Vol. 14 No. 3, 305-321
}

An increasing number of studies, inspired by Positive Psychology movement, have focused on the roles positive affect (PA) plays. The present article, first of all, sought to clarify some of the problems concerning definition and measurement of PA. Specifically, it was emphasized that many types of PA remained unexamined, and that measurement accuracy of existent scales was very low. Secondly, in comparison with the roles of negative affect (NA), a number of benefits produced by PA were reviewed in such broad domains as cognition, information processing, health, social relations, and so on. In doing so, considerable thought has gone into analyzing previous inconsistencies in PA and NA findings, so that consistent notions concerning both affects may become possible. Lastly, the present article elucidated several hypothetical mechanisms underlying the benefits. Throughout this article, the author considered crucial problems underlying this broad-range research, which could simultaneously suggest future studies that were especially needed. It was suggested that the future studies would mainly consist of cultural differences and intervention.

Key words: positive affect (PA), negative affect (NA), roles of PA, mechanisms underlying PA benefits 